\title{
Decreased T cell reactivity to Epstein-Barr virus infected lymphoblastoid cell lines in multiple sclerosis
}

\author{
M P Pender, ${ }^{1,2}$ P A Csurhes, ${ }^{3}$ A Lenarczyk, ${ }^{1}$ C M M Pfluger, ${ }^{3}$ S R Burrows ${ }^{4}$
}

\section{See Editorial Commentary, p469}

${ }^{1}$ The University of Queensland, School of Medicine, Queensland, Australia; ${ }^{2}$ Department of Neurology, Royal Brisbane and Women's Hospital, Queensland, Australia; ${ }^{3}$ The University of Queensland Centre for Clinical Research, Queensland, Australia; ${ }^{4}$ Queensland Institute of Medical Research, Queensland, Australia

Correspondence to: Professor M P Pender, Discipline of Medicine, Clinical Sciences Building, Royal Brisbane and Women's Hospital, Queensland 4029, Australia;

m.hawes@uq.edu.au

Received 18 August 2008 Revised 13 October 2008 Accepted 24 October 2008 Published Online First 17 November 2008

\begin{abstract}
Objective: To investigate T cell and antibody immunity to Epstein-Barr virus (EBV) in multiple sclerosis (MS).

Methods: Immunoglobulin G (lgG) immunity to EBV nuclear antigen 1 (EBNA1) and viral capsid antigen was measured by enzyme linked immunosorbent assays, and $T$ cell immunity was assessed using enzyme linked immunospot assays to measure the frequency of peripheral blood mononuclear cells (PBMC) producing interferon $\gamma$ in response to autologous EBV infected B cell lymphoblastoid cell lines (LCL) in 34 EBV seropositive healthy subjects and 34 EBV seropositive patients with MS who had not received immunomodulatory therapy in the previous 3 months.
\end{abstract}

Results: Patients with MS had increased levels of antiEBNA1 lgG but a decreased frequency of LCL specific T cells compared with healthy subjects. Using purified populations of $\mathrm{CD}^{+} \mathrm{T}$ cells and $\mathrm{CD} 8^{+} \mathrm{T}$ cells, we showed that the LCL specific response resides predominantly in the $\mathrm{CD}^{+}$population, with a frequency 5-7-fold higher than in the $\mathrm{CD}^{+}$population. The decreased $\mathrm{CD} 8^{+} \mathrm{T}$ cell response to $L C L$ in $M S$ was not caused by decreased $H L A$ class I expression by LCL, and LCL from MS patients could be killed normally by HLA matched EBV specific cytotoxic $\mathrm{CD}^{+} \mathrm{T}$ cell clones from healthy subjects. Furthermore, the decreased $\mathrm{CD}^{+} \mathrm{T}$ cell immunity to EBV was not due to a primary defect in the function of $\mathrm{CD}^{+} \mathrm{T}$ cells because EBV specific cytotoxic CD8 ${ }^{+} T$ cell lines could be generated normally from the PBMC of patients with MS. Conclusion: This quantitative deficiency in $\mathrm{CD}^{+} \mathrm{T}$ cell immunity to EBV might be responsible for the accumulation of EBV infected $B$ cells in the brains of patients with MS.

A large body of evidence indicates that multiple sclerosis (MS) is an autoimmune disease ${ }^{12}$ but the primary cause of MS and the other human chronic autoimmune diseases is as yet unknown. Epidemiological studies indicate that infection with the Epstein-Barr virus (EBV) has a role in the pathogenesis of $\mathrm{MS}^{3}$ In a meta-analysis of 13 case control studies comparing EBV serology in patients with MS and controls, $99.5 \%$ of patients with MS were EBV seropositive compared with $94.0 \%$ of controls, with EBV seronegativity having an $\mathrm{OR}_{\mathrm{MH}}$ odds ratio of $\mathrm{MS}$ of 0.06 (exact $95 \%$ confidence interval 0.03 to 0.13 ; $p<0.000000001) .{ }^{3}$ Furthermore, children with MS have an EBV seropositivity rate of $98.6 \%$ compared with $72.1 \%$ in age matched controls. ${ }^{4}$ These studies suggest that EBV infection is a prerequisite for the development of MS.

EBV has the unique ability to infect, activate and latently persist in B lymphocytes. When EBV infects resting $B$ cells, it drives them into activation and proliferation independently of $\mathrm{T}$ cell help. Usually, the proliferating infected $B$ cells are eventually eliminated by EBV specific cytotoxic $\mathrm{CD}^{+} \mathrm{T}$ cells but latently infected non-proliferating memory B cells persist in the individual for life. ${ }^{5}$ We have hypothesised that a genetically determined defect in the elimination of EBV infected $B$ cells by cytotoxic $\mathrm{CD}^{+} \mathrm{T}$ cells might predispose to the development of MS by allowing the accumulation of EBV infected autoreactive $\mathrm{B}$ cells in the CNS. ${ }^{6}$ Recently it has been demonstrated that a substantial proportion of the B cells and plasma cells in the MS brain are infected with EBV.?

Several studies have investigated $\mathrm{T}$ cell immunity to EBV in $\mathrm{MS}$ and have yielded conflicting results. Craig and colleagues ${ }^{8}$ found that patients with MS have decreased $\mathrm{T}$ cell control of the number of immunoglobulin (Ig) secreting B cells after in vitro infection with EBV. Using a panel of five HLA-A2 restricted EBV peptides and one HLAB7 restricted EBV peptide, Höllsberg and colleagues $^{9}$ found an increased frequency of $\mathrm{CD}^{+} \mathrm{T}$ cells reactive to two immunodominant $\mathrm{EBV}$ epitopes in patients with MS. However, another study ${ }^{10}$ found no differences in the $\mathrm{CD}^{+} \mathrm{T}$ cell frequencies between patients with MS and healthy controls for seven HLA-B7 restricted EBV peptides, including one of the peptides found by Höllsberg and colleagues $^{9}$ to elicit an increased response. Using a pool of 18 HLA class I restricted EBV peptides, Jilek and colleagues $^{11}$ found an increased EBV specific $\mathrm{CD}^{+} \mathrm{T}$ cell response in patients with clinically isolated syndromes but a normal response in established MS whereas another study found that patients with MS had an increased $\mathrm{CD}^{+} \mathrm{T}$ cell response to peptides derived from EBV nuclear antigen-1 (EBNA1). ${ }^{12}$

Studies on T cell immunity using selected EBV peptides are limited by the fact that they do not provide a measure of the total $\mathrm{T}$ cell response to EBV, which encodes many different proteins. In the present study we have investigated $\mathrm{T}$ cell immunity to EBV in MS, focusing on the total $\mathrm{T}$ cell response to EBV infected $B$ cells using EBV infected B cell lymphoblastoid cell lines (LCL) as stimulators. LCL express not only the latent proteins of EBV but also the lytic proteins, ${ }^{13} 14$ owing to the fact that a proportion of the cells in LCL are in the lytic phase of infection. Our specific aims were to determine: (1) whether the frequency of $\mathrm{T}$ cells specific for EBV infected B cells is increased or decreased in patients with MS; (2) whether EBV infected B cells of patients with MS online under the BMJ Journals unlocked scheme, see http:// jnnp.bmj.com/info/unlocked.dtl 
can be killed by cytotoxic CD8 $\mathrm{T}$ cells from HLA matched healthy subjects; (3) whether EBV specific $\mathrm{CD}^{+} \mathrm{T}$ cells generated in vitro from patients with MS can kill EBV infected $\mathrm{B}$ cells; and (4) whether there is a correlation between $\mathrm{T}$ cell and antibody immunity to EBV.

\section{METHODS \\ Subjects}

Blood $(60 \mathrm{ml})$ was collected from 34 EBV seropositive healthy subjects and 34 EBV seropositive patients with MS following informed consent. This study was approved by the Royal Brisbane and Women's Hospital Human Research Ethics Committee and the University of Queensland Medical Research Ethics Committee. All patients met the 2005 Revised McDonald criteria for a diagnosis of MS. ${ }^{15}$ The clinical course was relapsing-remitting in 14 patients, secondary progressive in 11 and primary progressive in nine. Patients had not received corticosteroids or immunomodulatory therapy for at least 3 months prior to venesection. Only five of the patients had ever received interferon $\beta$, glatiramer acetate or immunosuppressant drugs, and in three of these the treatment had been stopped at least 2 years before blood was collected for this study. Disability was assessed using the Kurtzke Expanded Disability Status Scale (EDSS) ${ }^{16}$ and the MS Severity Score (MSSS) was determined from the EDSS and disease duration. ${ }^{17}$ The demographic and clinical details of the healthy subjects and patients with MS are presented in table 1. Subjects were Caucasian except for one healthy subject and two patients with MS who were Asian.

\section{Processing of blood samples}

Blood (10 ml) was used for DNA extraction and HLA typing, and $5 \mathrm{ml}$ for serum collection. Peripheral blood mononuclear cells (PBMC) were separated by density centrifugation, resuspended in complete RPMI (RPMI-C) with 10\% dimethyl sulphoxide (Sigma, St Louis, Missouri, USA) and cryopreserved in liquid nitrogen. RPMI-C was prepared by supplementing RPMI-1640 tissue culture medium (Invitrogen, Carlsbad, California, USA) with 10\% heat inactivated fetal calf serum (Cambrex, Walkersville, Maryland, USA), $2 \mathrm{mM}$ L-glutamine (Lonza, Walkersville, Maryland, USA), $50 \mathrm{U} / \mathrm{ml}$ penicillin (Invitrogen), $50 \mu \mathrm{g} / \mathrm{ml}$ streptomycin (Invitrogen) and $0.01 \mathrm{M}$ HEPES buffer (Lonza, Walkersville, Maryland, USA).

\section{Antiviral antibodies}

Serum samples were diluted in doubling dilutions ranging from $1 / 12.5$ to $1 / 12800$ and tested using enzyme linked immunosorbent assay (ELISA) kits (Inverness Medical, Brisbane, Australia) to determine the titres of IgG specific for EBNA1 and EBV viral capsid antigen (VCA).

Table 1 Characteristics of healthy subjects and patients with MS

\begin{tabular}{lll}
\hline & HC & MS \\
\hline $\mathrm{n}$ & 34 & 34 \\
Female sex (n) & 26 & 19 \\
Mean age (years) & $39.5(9.9)$ & $43.8(11.8)$ \\
Mean age of onset of MS (years) & & $34.1(10.9)$ \\
Mean duration of MS (years) & & $10.1(7.6)$ \\
Mean EDSS & & $4.8(2.4)$ \\
Mean MSSS & $6.2(3.0)$ \\
\hline
\end{tabular}

EDSS, Expanded Disability Status Scale; HC, healthy control subjects; MS, multiple sclerosis; MSSS, MS Severity Score.

\section{HLA typing}

Genomic DNA was extracted from $10 \mathrm{ml}$ of heparinised blood using NucleoSpin Blood XL DNA extraction kits (MachereyNagel, Düren, Germany). Low resolution sequence specific primer kits (Dynal Biotech, Oslo, Norway) were used to type for HLA-A, HLA-B, HLA-DR, HLA-DOA and HLA-DOB.

\section{Generation of LCL and assessment by flow cytometry}

LCL were generated from each subject by incubating 50000 washed PBMC with the B95-8 strain of EBV overnight in $1 \mathrm{ml}$ of RPMI-C supplemented with $2 \mu \mathrm{g} / \mathrm{ml}$ ciclosporin (Sigma). LCL were cultured in this medium for 1 month followed by at least another 2 months of culture in RPMI-C without ciclosporin until confluent rapidly growing lines were obtained. These LCL were flow cytometrically assessed after 3 months of culture to confirm that they contained only $\mathrm{CD} 19^{+} \mathrm{B}$ cells, with no contaminating $\mathrm{CD}^{+} \mathrm{T}$ cells, before being used in ELISPOT assays, cytotoxicity assays or for the generation of LCL specific $\mathrm{T}$ cell lines. To quantify HLA class I expression by LCL, healthy log phase cultures of LCL were stained with R-PE labelled antihuman HLA-ABC (BD Pharmingen, San Diego, California, USA).

\section{ELISPOT assays}

To measure the total $\mathrm{T}$ cell response to $\mathrm{EBV}$ infected $\mathrm{B}$ cells, we incubated PBMC with autologous LCL. PBMC were thawed from liquid nitrogen storage and incubated in RPMI-C for $24 \mathrm{~h}$ before use to allow re-expression of cell surface receptors. After counting and assessment for viability by trypan blue staining, PBMC were cultured in quadruplicate with either 50000 or 5000 cells per well in $200 \mu \mathrm{l}$ volumes of RPMI-C in the presence of 50000 autologous LCL or in the absence of LCL for $48 \mathrm{~h}$. Interferon $\gamma$ (IFN $\gamma$ ) enzyme linked immunospot (ELISPOT) assays were conducted using a commercially available kit (Mabtech, Stockholm, Sweden), according to the manufacturer's instructions. The average number of IFN $\gamma$ spot forming cells (SFC) per well in the presence of PBMC and absence of LCL, and the average number of SFC per well in the presence of LCL and absence of PBMC were added together for each subject. The sum of these backgrounds was subtracted from the average number of SFC per well in the presence of both PBMC and LCL, with the difference expressed as the number of LCL specific IFN $\gamma$ SFC per $10^{6}$ PBMC. The mean background for PBMC alone was 7 (7) SFC per $10^{6}$ cells in healthy subjects and 13 (19) SFC per $10^{6}$ cells in patients with $\mathrm{MS}$, and the mean background for LCL alone was 33 (53) SFC per $10^{6}$ cells in healthy subjects and 73 (90) SFC per $10^{6}$ cells in patients with MS. In some subjects we also used the IFN $\gamma$ ELISPOT assay to measure the frequency of PBMC specific for synthetic EBV peptides by incubating $200000 \mathrm{PBMC}$ per well with and without $10 \mu \mathrm{g} / \mathrm{ml}$ of each peptide.

\section{T cell cytotoxicity assays}

Chromium release assays were performed to measure the killing of LCL by a panel of five non-autologous HLA matched EBV specific $\mathrm{CD} 8^{+} \mathrm{T}$ cell clones derived from healthy subjects in previous studies by SRB. ${ }^{18} \mathrm{LCL}$ were washed, labelled for $60 \mathrm{~min}$ with $3.7 \times 10^{6} \mathrm{~Bq}$ of ${ }^{51} \mathrm{Cr}\left(\mathrm{Na}_{2} \mathrm{Cr}_{3} \mathrm{O}_{4}\right)$ at $37^{\circ} \mathrm{C}$ and then washed twice with medium. The ${ }^{51} \mathrm{Cr}$-labelled target cells ( $10^{4}$ per well) were mixed with $\mathrm{T}$ cells from HLA matched $\mathrm{T}$ cell clones at effector:target ratios of 4:1 and 2:1 in 96 well round bottomed plates in $200 \mu \mathrm{l}$ volumes. After $5 \mathrm{~h}$ of incubation, $25 \mu \mathrm{l}$ of supernatant from each well were counted in a $\beta$ scintillation 


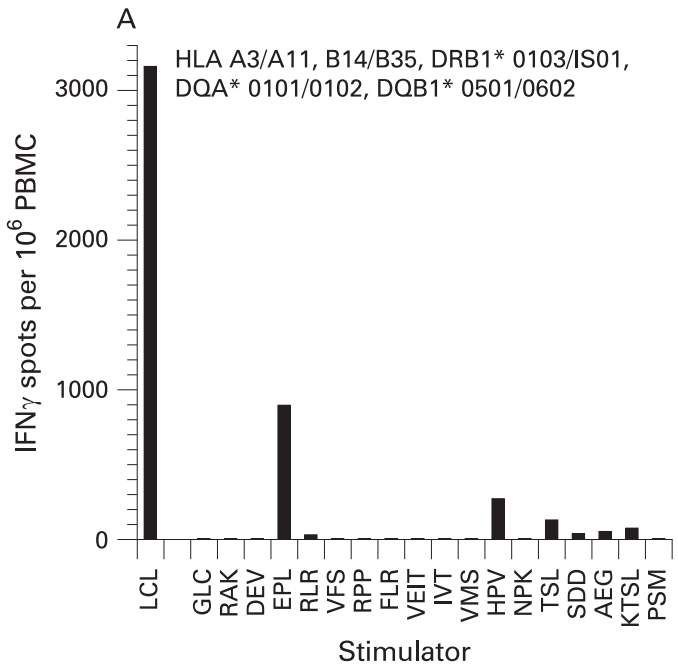

B

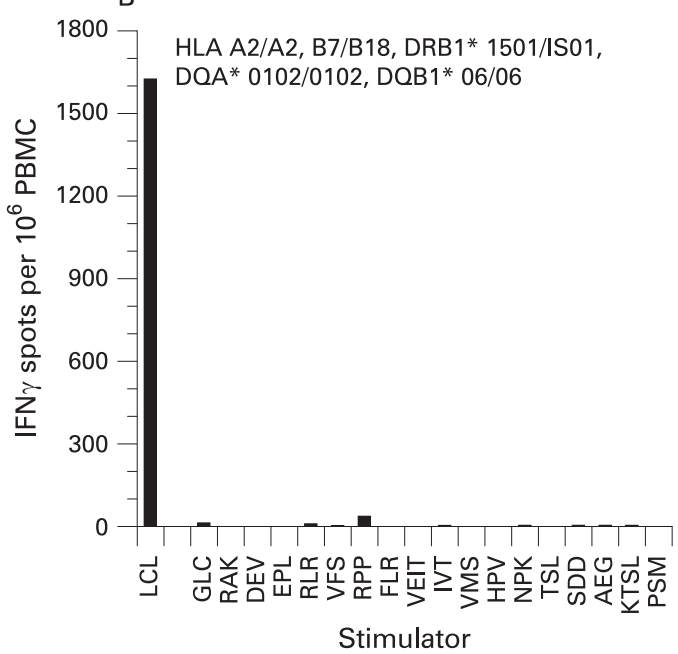

Figure 1 Frequencies of T cells producing interferon $\gamma($ IFN $\gamma$ ) in response to autologous lymphoblastoid cell lines (LCL) and to individual synthetic peptides derived from Epstein-Barr virus (EBV) proteins in an EBV seropositive healthy subject $(A)$ and an EBV seropositive multiple sclerosis (MS) patient (B). Each peptide is represented by the first three amino acids of its sequence. In the healthy subject (A), the highest response to any peptide was against EPLPQGOLTAY, derived from the EBV lytic cycle protein BZLF1 and restricted by HLA-B35, which was carried by this subject. The next highest peptide response was against HPVGEADYFEY, derived from the latent cycle protein EBNA1 and also restricted by HLA-B35. The third highest response was against TSLYNLRRGTALAl, derived from EBNA1 and restricted by HLA-DR1, which was carried by this subject. The other peptides, proteins from which they are derived and their HLA restriction elements are as follows: GLC, GLCTLVAML from BMLF1, HLA-A2; RAK, RAKFKOLL from BZLF1, HLA-B8; DEV, DEVEPLGHY from BMLF1, HLA-B18; RLR, RLRAEAOVK from EBNA3A, HLA-A3; VFS, VFSDGRVAC from EBNA3A, HLA-A29; RPP, RPPIFIRRL from EBNA3A, HLA-B7; FLR, FLRGRAYGL from EBNA3A, HLA-B8; VEIT, VEITPYKPTW from EBNA3B, HLA-B44; IVT, IVTDFSVIK from EBNA3B, HLA-A11; VMS, VMSNTLLSAW from latent membrane protein 2, HLA-A25; NPK, NPKFENIAEGLRALL from EBNA1, HLA-DR11; SDD, SDDELPYIDPNMEPV from EBNA3C, HLA-DR11; AEG, AEGLRALLARSHVER from EBNA1, HLA-DR15; KTSL, KTSLTNLRRGTALA from EBNA1, HLA-DR7; and PSM, PSMPFASDYSOGAFT from EBNA3C, HLA-DR4. In the patient with MS (B), the highest response to any peptide was against RPPIFIRRL, derived from the EBV latent cycle protein EBNA3A and restricted by HLA-B7, which was carried by this patient. In both subjects the sum of the responses to the 18 individual peptides tested was much lower than the response to the LCL.

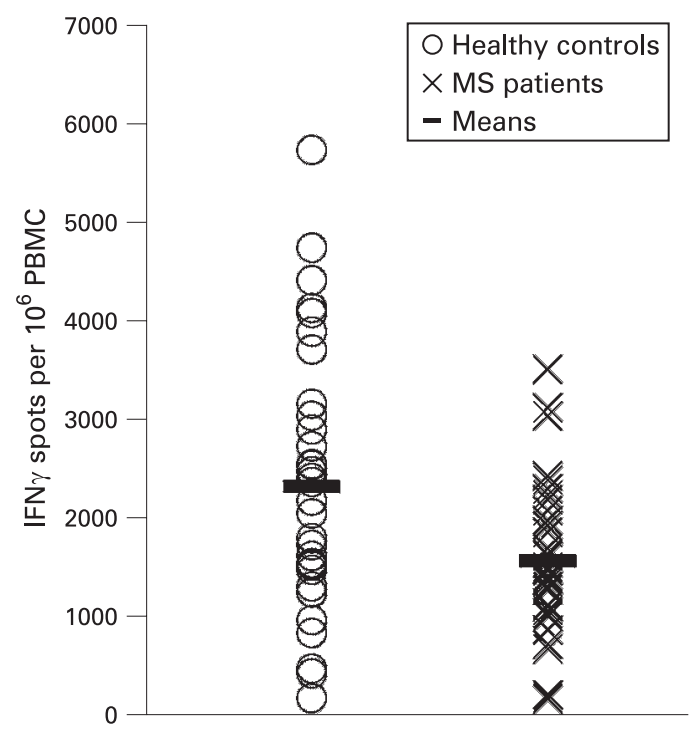

Figure 2 Frequencies of peripheral blood mononuclear cell (PBMC) producing interferon $\gamma$ (IFN $\gamma$ ) in response to autologous lymphoblastoid cell lines (LCL) in 34 Epstein-Barr virus (EBV) seropositive healthy subjects and 34 EBV seropositive patients with multiple sclerosis (MS). The mean frequency in patients with MS (1573 (798) per $10^{6}$ PBMC) was significantly lower than the mean in healthy subjects (2326 (1314) per $10^{6}$ PBMC) $(p=0.006$, heteroscedastic $t$ test $)$.

counter (Packard Instrument, Meriden, Connecticut, USA). Maximum release and spontaneous release of ${ }^{51} \mathrm{Cr}$ were measured in wells containing target cells in the presence of $10 \%$ sodium dodecyl sulphate or medium alone, respectively. The per cent specific lysis was calculated by the formula:

$\%$ specific lysis $=$ (test release - spontaneous release)/ (maximum release - spontaneous release) $\times 100$.

\section{Generation and testing of EBV specific $T$ cell lines}

To generate EBV specific $T$ cell lines, PBMC were incubated with $10^{6}$ irradiated (80 Gy) autologous LCL (stimulator to responder ratio of 1:10) in RPMI-C without interleukin 2 (IL2) in 24 well tissue culture plates. Eleven days later, each cell line was restimulated with irradiated autologous LCL, and from day 13 the medium was supplemented with $20 \mathrm{U} / \mathrm{ml}$ recombinant IL2. A third stimulation with irradiated autologous LCL was given on day 22. Cultures were immunophenotyped by flow cytometry and tested for cytotoxic capacity at day 40. The T cell lines were assessed by flow cytometry to determine the proportions of $\mathrm{CD}^{+} \mathrm{CD}^{+} \mathrm{T}$ cells, $\mathrm{CD}^{+} \mathrm{CD}^{+} \mathrm{T}$ cells and $\mathrm{CD} 16^{+} \mathrm{CD}^{-} / \mathrm{CD}^{2} 6^{+} \mathrm{CD}^{-} \mathrm{NK}$ cells using directly conjugated antibodies (BD Pharmingen, San Diego, California, USA). The cytotoxic capacity of the $\mathrm{T}$ cell lines was determined by $5 \mathrm{~h}$ chromium release assays using autologous LCL and HLA mismatched LCL as targets, with effector:target ratios of 20:1, $10: 1,5: 1$ and $2.5: 1$.

\section{Statistical analysis}

Statistical analyses were performed using SigmaStat 3.11.0 (Systat Software, Inc., San Jose, California, USA). For comparisons between patients with MS and healthy subjects when the data were normally distributed, the means were compared using the Student's t test. If the data were not normally distributed, the medians were compared using the Mann-Whitney rank sum test. Differences between means or between medians were considered significant if $p \leqslant 0.05$. Means are presented as mean 
Table 2 HLA class I and class II typing

\begin{tabular}{|c|c|c|c|c|c|}
\hline \multicolumn{3}{|l|}{ HLA class I } & \multicolumn{3}{|c|}{ HLA class II } \\
\hline HLA allele & HC (n (\%))† & MS (n (\%)) & HLA allele & HC (n (\%)) & MS (n (\%)) \\
\hline$A^{*} 01$ & $9(26.5)$ & $6(17.6)$ & $\mathrm{DRB} 1{ }^{*} 01$ & $7(20.6)$ & $7(20.6)$ \\
\hline$A^{*} 02$ & $16(47.1)$ & $11(32.4)$ & DRB1*15 & $12(35.3)$ & $18(52.9)$ \\
\hline$A^{*} 03$ & $10(29.4)$ & $11(32.4)$ & $\mathrm{DRB} 1 * 16$ & $0(0.0)$ & $2(5.9)$ \\
\hline$A^{*} 11$ & $4(11.8)$ & $7(20.6)$ & $\mathrm{DRB} 1 * 03$ & $9(26.5)$ & $7(20.6)$ \\
\hline$A^{*} 23$ & $5(14.7)$ & $1(2.9)$ & $\mathrm{DRB} 1{ }^{*} 04$ & $13(38.2)$ & $6(17.6)$ \\
\hline$A^{*} 24$ & $2(5.9)$ & $6(17.6)$ & DRB1*11 & $5(14.7)$ & $3(8.8)$ \\
\hline$A^{*} 25$ & $2(5.9)$ & $2(5.9)$ & DRB1*12 & $1(2.9)$ & $2(5.9)$ \\
\hline$A^{*} 26$ & $1(2.9)$ & $0(0.0)$ & DRB1*13 & $7(20.6)$ & $5(14.7)$ \\
\hline$A^{*} 29$ & $2(5.9)$ & $0(0.0)$ & DRB1*14 & $2(5.9)$ & $0(0.0)$ \\
\hline$A^{*} 30$ & $1(2.9)$ & $1(2.9)$ & DRB $1 * 07$ & $8(23.5)$ & $6(17.6)$ \\
\hline$A^{*} 31$ & $0(0.0)$ & $3(8.8)$ & $\mathrm{DRB} 1{ }^{*} 08$ & $2(5.9)$ & $2(5.9)$ \\
\hline$A^{*} 32$ & $2(5.9)$ & $3(8.8)$ & DRB1*09 & $0(0.0)$ & $0(0.0)$ \\
\hline$A^{*} 33$ & $1(2.9)$ & $1(2.9)$ & DRB1*10 & $1(2.9)$ & $2(5.9)$ \\
\hline$A^{*} 36$ & $0(0.0)$ & $2(5.9)$ & & & \\
\hline$A^{*} 68$ & $1(2.9)$ & $2(5.9)$ & $\mathrm{DQA} 1 * 01$ & $26(76.5)$ & $28(82.4)$ \\
\hline$A^{*} 74$ & $1(2.9)$ & $0(0.0)$ & $\mathrm{D} 0 \mathrm{~A} 1 * 02$ & $8(23.5)$ & $7(20.6)$ \\
\hline \multirow[t]{2}{*}{$A^{*} 92$} & $1(2.9)$ & $0(0.0)$ & $\mathrm{DQA} 1 * 03$ & $14(41.2)$ & $6(17.6)$ \\
\hline & & & DQA $1 * 04$ & $2(5.9)$ & $3(8.8)$ \\
\hline$B * 07$ & $7(20.6)$ & $14(41.2)$ & DQA $1 * 05$ & $14(41.2)$ & $11(32.4)$ \\
\hline$B * 08$ & $7(20.6)$ & $6(17.6)$ & & & \\
\hline$B * 13$ & $4(11.8)$ & $3(8.8)$ & $\mathrm{DQB} 1 * 02$ & $15(44.1)$ & $11(32.4)$ \\
\hline$B * 14$ & $4(11.8)$ & $2(5.9)$ & $\mathrm{DQB} 1 * 03$ & $17(50.0)$ & $13(38.2)$ \\
\hline$B * 15$ & $4(11.8)$ & $2(5.9)$ & $\mathrm{DOB} 1 * 04$ & $1(2.9)$ & $2(5.9)$ \\
\hline$B * 18$ & $2(5.9)$ & $4(11.8)$ & $\mathrm{DQB} 1 * 05$ & $10(29.4)$ & $11(32.4)$ \\
\hline$B * 27$ & $2(5.9)$ & $1(2.9)$ & $\mathrm{DOB} 1 * 06$ & $18(52.9)$ & $21(61.8)$ \\
\hline$B * 35$ & $4(11.8)$ & $8(23.5)$ & & & \\
\hline$B * 37$ & $2(5.9)$ & $1(2.9)$ & & & \\
\hline$B * 38$ & $1(2.9)$ & $1(2.9)$ & & & \\
\hline$B * 39$ & $1(2.9)$ & $4(11.8)$ & & & \\
\hline$B * 40$ & $4(11.8)$ & $4(11.8)$ & & & \\
\hline$B * 44$ & $12(35.3)$ & $6(17.6)$ & & & \\
\hline$B * 49$ & $2(5.9)$ & $0(0.0)$ & & & \\
\hline$B * 51$ & $4(11.8)$ & $1(2.9)$ & & & \\
\hline$B * 52$ & $1(2.9)$ & $1(2.9)$ & & & \\
\hline$B * 53$ & $0(0.0)$ & $1(2.9)$ & & & \\
\hline$B * 55$ & $2(5.9)$ & $2(5.9)$ & & & \\
\hline$B * 57$ & $1(2.9)$ & $4(11.8)$ & & & \\
\hline
\end{tabular}

$†$ Number (\%) of subjects carrying each allele, either heterozygously or homozygously.

HC, 34 healthy control subjects; MS, 34 patients with multiple sclerosis.

(SD). To compare the proportions of subjects with each titre of anti-EBNA1 or anti-VCA IgG, we used the $\chi^{2}$ test with Yates' correction as required. To measure the correlation between data, the parametric Pearson product moment correlation was used for normally distributed data, and the Spearman rank order correlation was used for non-parametric data.

\section{RESULTS}

\section{Patients with MS have decreased T cell immunity to EBV}

In preliminary studies we used ELISPOT assays to determine the frequency of PBMC producing IFN $\gamma$ in response to synthetic peptides derived from a variety of EBV proteins and restricted by HLA molecules commonly carried by patients with MS. When analysing these experiments, three problems became apparent. Firstly, the T cell responses to any given EBV peptide could be compared only between those subjects who carried the restricting HLA molecule. Secondly, the use of selected EBV peptides did not provide a measure of the total $T$ cell response to EBV in any subject. Thirdly, the use of peptides bypasses the normal physiological process of antigen processing. Thus a person might have a high frequency of $\mathrm{T}$ cells producing IFN $\gamma$ in response to an exogenously added synthetic EBV peptide which is presented at a low density on the surface of EBV infected $B$ cells so that the infected $B$ cells are poorly recognised by peptide specific T cells. ${ }^{19}$

To overcome these problems, we measured the frequency of PBMC producing IFN $\gamma$ in response to autologous LCL. This approach provides a direct measure of the aggregate $\mathrm{T}$ cell response to EBV infected $B$ cells in each subject and also allows comparisons between subjects regardless of which HLA genes are carried. Figure 1 shows that the sum of the responses to the 18 individual synthetic peptides tested is much lower than the response to the LCL in a given subject. By extracting purified populations of $\mathrm{CD}^{+} \mathrm{T}$ cells, $\mathrm{CD}^{+} \mathrm{T}$ cells and $\mathrm{NK}$ cells from PBMC using immunomagnetic beads, we found that LCL specific $\mathrm{T}$ cells were $5-7$-fold more frequent in the $\mathrm{CD}^{+} \mathrm{T}$ cell population than in the $\mathrm{CD}^{+} \mathrm{T}$ cell population and less frequent again in the NK cell population (not shown).

We then measured the T cell reactivity against LCL in 34 EBV seropositive healthy subjects and 34 EBV seropositive patients with MS (fig 2). The specificity of this response as a measure of EBV immunity was demonstrated by the fact that the 
Table 3 Susceptibility of LCL to killing by HLA matched EBV specific CD8 ${ }^{+}$T cell clones from healthy subjects

\begin{tabular}{|c|c|c|c|c|c|c|}
\hline \multirow[b]{3}{*}{ Subject } & \multicolumn{6}{|c|}{ Per cent specific lysis of LCL by T cell clone } \\
\hline & \multicolumn{2}{|c|}{$\begin{array}{l}\text { HLA-A3* RLRAEAQVK } \dagger \\
\text { clone JC/RLR2 }\end{array}$} & \multicolumn{2}{|c|}{$\begin{array}{l}\text { HLA-B7 RPPIFIRRL } \\
\text { clone J0/RPPI7§ }\end{array}$} & \multicolumn{2}{|c|}{$\begin{array}{l}\text { HLA-A11 AVFDRKSDAK } \\
\text { clone CM/AVF29§ }\end{array}$} \\
\hline & $\mathrm{E}: \mathrm{T}=4: 1$ & $\mathrm{E}: \mathrm{T}=2: 1$ & $\mathrm{E}: \mathrm{T}=4: 1$ & $\mathrm{E}: \mathrm{T}=2: 1$ & $\mathrm{E}: \mathrm{T}=4: 1$ & $\mathrm{E}: \mathrm{T}=2: 1$ \\
\hline HC 2 & 42.3 & 30.2 & & & & \\
\hline HC 5 & & & 5.4 & 4.4 & & \\
\hline HC 9 & & & 17.3 & 15.2 & & \\
\hline HC 11 & 46.2 & 34.1 & 21.0 & 16.9 & & \\
\hline HC 14 & 62.8 & 49.5 & & & & \\
\hline HC 15 & 26.1 & 23.1 & 20.4 & 18.2 & & \\
\hline HC 16 & 37.2 & 29.5 & & & 49.4 & 50.7 \\
\hline HC 21 & 38.3 & 31.6 & 9.9 & 9.7 & & \\
\hline HC 25 & & & & & 31.4 & 31.5 \\
\hline HC 26 & 40.3 & 32.2 & & & & \\
\hline HC 30 & & & 9.4 & 4.9 & & \\
\hline HC 34 & & & & & 26.0 & 27.5 \\
\hline Mean HC & $41.9(11.1)$ & $32.9(8.1)$ & $13.9(6.5)$ & $11.6(6.1)$ & $35.6(12.3)$ & $36.6(12.4)$ \\
\hline MS 143 & 62.8 & 47.2 & 31.5 & 25.1 & & \\
\hline MS 187 & 71.3 & 60.3 & 11.8 & 10.1 & & \\
\hline MS 188 & & & 25.4 & 21.8 & 53.7 & 52.2 \\
\hline MS 196 & 39.9 & 31.5 & 16.3 & 15.8 & & \\
\hline MS 200 & 37.5 & 33.8 & 8.5 & 6.5 & & \\
\hline MS 201 & 57.1 & 38.0 & & & & \\
\hline MS 212 & & & 13.7 & 12.8 & & \\
\hline MS 215 & & & 11.1 & 11.1 & 31.1 & 30.9 \\
\hline MS 329 & & & 4.4 & 1.6 & 12.6 & 14.6 \\
\hline MS 419 & 33.9 & 30.7 & 10.1 & 10.2 & & \\
\hline MS 442 & 45.9 & 35.8 & & & & \\
\hline MS 468 & 49.5 & 42.0 & & & & \\
\hline Mean MS & $49.7(13.1)$ & $39.9(9.9)$ & $14.8(8.6)$ & $12.8(7.3)$ & $32.5(20.6)$ & $32.6(18.9)$ \\
\hline p Valuet & 0.24 & 0.16 & 0.84 & 0.74 & 0.83 & 0.77 \\
\hline
\end{tabular}

Table 4 Phenotype and cytotoxicity of LCL specific T cell lines

\begin{tabular}{|c|c|c|c|c|c|c|c|}
\hline \multirow[b]{3}{*}{ Subject } & \multirow{2}{*}{\multicolumn{3}{|c|}{ Phenotype of $\mathrm{T}$ cell line (\%) }} & \multicolumn{4}{|c|}{ Per cent specific lysis of LCL } \\
\hline & & & & \multicolumn{2}{|c|}{ Autologous LCL } & \multicolumn{2}{|c|}{ HLA mismatched LCL } \\
\hline & $\mathrm{CD4}^{+}$ & $\mathrm{CD8}^{+}$ & NK & $\mathrm{E}: \mathrm{T}=20: 1$ & $E: T=10: 1$ & $E: T=20: 1$ & $E: T=10: 1$ \\
\hline $\mathrm{HC} 4$ & 7.7 & 86.9 & 0.9 & 46.5 & 37.4 & 13.4 & 8.1 \\
\hline HC 12 & 16.1 & 85.3 & 1.1 & 40.2 & 36.2 & 6.3 & 6.0 \\
\hline HC 14 & 59.4 & 31.7 & 0.6 & 36.8 & 27.1 & 10.1 & 6.5 \\
\hline HC 24 & 29.5 & 67.2 & 2.8 & 54.3 & 49.4 & 19.1 & 15.1 \\
\hline HC 31 & 23.4 & 71.9 & 3.8 & 52.4 & 43.1 & 9.1 & 7.6 \\
\hline HC 32 & 47.8 & 45.2 & 0.7 & 49.0 & 40.9 & 6.1 & 5.5 \\
\hline Mean HC & $30.6(19.6)$ & $64.7(22.1)$ & $1.0^{*}$ & $46.5(6.9)$ & $39.0(7.5)$ & & \\
\hline MS 192 & 60.9 & 38.8 & 1.0 & 17.0 & 7.1 & -1.7 & -5.1 \\
\hline MS 210 & 20.3 & 73.2 & 3.5 & 69.2 & 63.3 & 12.1 & 9.1 \\
\hline MS 211 & 45.3 & 54.8 & 0.5 & 39.3 & 29.5 & 2.3 & 3.7 \\
\hline MS 212 & 7.6 & 90.0 & 1.7 & 45.5 & 30.1 & 9.0 & 5.4 \\
\hline MS 215 & 40.5 & 60.1 & 1.1 & 46.3 & 35.4 & 5.4 & 2.1 \\
\hline MS 428 & 19.0 & 63.3 & 8.7 & 95.1 & 96.2 & 15.9 & 14.9 \\
\hline Mean MS & $32.3(19.9)$ & $63.4(17.3)$ & $1.4^{*}$ & $52.1(26.9)$ & $43.6(31.4)$ & & \\
\hline p Value $\dagger$ & 0.89 & 0.91 & $0.70 t$ & 0.64 & 0.74 & & \\
\hline
\end{tabular}

*Median.

†Student's t test for comparison between Mean HC and Mean MS.

:Mann-Whitney rank sum test for comparison of median per cent NK cells between HC and MS.

$\mathrm{E}: \mathrm{T}$, effector:target ratio; LCL, lymphoblastoid cell lines; Mean HC, mean (SD) in healthy control subjects; Mean MS, mean (SD) in patients with multiple sclerosis. 
frequency in an EBV seronegative healthy subject was only 80 per $10^{6} \mathrm{PBMC}$, which was much lower than the mean in EBV seropositive healthy subjects. The mean LCL specific $\mathrm{T}$ cell frequency in the EBV seropositive patients with MS was 1573 (798) per $10^{6} \mathrm{PBMC}$, which was significantly lower than that in EBV seropositive healthy subjects (2326 (1314) per $10^{6} \mathrm{PBMC}$; $p=0.006)$ (fig 2$)$. The mean LCL specific $T$ cell frequency per $10^{6} \mathrm{PBMC}$ was 1635 (898) in patients with relapsing-remitting MS, 1235 (437) in patients with secondary progressive MS and 1888 (897) in patients with primary progressive MS. The frequency in female patients (1551 (900) per $10^{6} \mathrm{PBMC}$ ) was similar to that in male patients $\left(1600\right.$ (677) per $10^{6} \mathrm{PBMC}$; $p=0.86)$. There were no significant correlations between the LCL specific T cell frequency and patient age, disease duration, EDSS or MSSS. Interestingly, there was a significant correlation between the $\mathrm{T}$ cell frequency and age of onset of $\mathrm{MS}(\mathrm{r}=0.38$; $p=0.028$ - that is, the lower the $T$ cell frequency the earlier the onset of MS.

These results indicate that patients with MS have a decreased $\mathrm{T}$ cell response to EBV infected $\mathrm{B}$ cells. Because EBV specific $\mathrm{T}$ cell IFN $\gamma$ production correlates with EBV specific $T$ cell cytotoxicity, ${ }^{20}$ this suggests that patients with MS have a defective ability to eliminate EBV infected B cells. One possible explanation for decreased $\mathrm{CD}^{+} \mathrm{T}$ cell reactivity to $\mathrm{LCL}$ is decreased HLA class I expression by LCL. The mean geometric mean fluorescence intensity of HLA class I on LCL was 434 (173) in healthy subjects and 425 (173) in patients with MS $(p=0.82)$, showing that the decreased T cell reactivity to LCL in patients with MS was not due to decreased HLA class I expression on LCL and was most likely due to an absolute decrease in the numbers of $\mathrm{CD}^{+} \mathrm{T}$ cells reacting to LCL.

\section{Decreased T cell immunity to EBV in MS is not explained by differences in HLA genes}

The results of HLA-A, HLA-B, HLA-DRB, HLA-DOA and HLA$\mathrm{DOB}$ typing are presented in table 2 . The main differences between patients with MS and healthy subjects were as follows: patients with MS carried $\mathrm{A}^{*} 02$ and $\mathrm{B}^{*} 44$ less frequently, and $\mathrm{B}^{*} 07$ and $\mathrm{DRB} 1^{*} 15$ more frequently, than healthy subjects, as previously described. ${ }^{21}$ There was no significant difference in the frequency of $\mathrm{T}$ cells producing IFN $\gamma$ against LCL between $\mathrm{HLA}_{-\mathrm{A}}{ }^{+}$and HLA-A2 ${ }^{-}$healthy subjects, between HLA-A2 ${ }^{+}$and HLA-A2 ${ }^{-}$patients with MS, between $\mathrm{HLA}^{-B 7^{+}}$and HLA-B7 ${ }^{-}$ healthy subjects, between $\mathrm{HLA}-\mathrm{B} 7^{+}$and $\mathrm{HLA}-\mathrm{B} 7^{-}$patients with MS, between HLA-B44+ and HLA-B44- healthy subjects, between HLA-B44+ and HLA-B44- $4^{-}$patients with MS, between HLA-DR15 ${ }^{+}$and HLA-DR15- healthy subjects or between HLA$\mathrm{DR}^{+} 5^{+}$and HLA-DR15 ${ }^{-}$patients with MS, indicating that differences in HLA genes carried by patients with MS and healthy subjects do not account for the decreased $\mathrm{T}$ cell response to LCL in patients with MS.

\section{EBV infected B cells from patients with MS are normally susceptible to killing by cytotoxic $\mathrm{CD8}^{+} \mathrm{T}$ cells}

To determine whether EBV infected B cells from patients with MS can be killed by EBV specific $\mathrm{CD}^{+} \mathrm{T}$ cells, we used chromium release assays to measure the killing of LCL by HLA matched EBV specific $\mathrm{CD}^{+} \mathrm{T}$ cell clones derived from healthy subjects (table 3 ). Using a $\mathrm{CD}^{+} \mathrm{T}$ cell clone specific for the HLA-A3 restricted RLRAEAQVK peptide of EBNA3A, ${ }^{22}$ we found that the killing of LCL from $\mathrm{HLA}-\mathrm{A}^{+}$patients with MS and healthy subjects was similar. With a $\mathrm{CD}^{+} \mathrm{T}$ cell clone specific for the HLA-B7 restricted RPPIFIRRL peptide of
EBNA3A, ${ }^{22}$ the killing of LCL from HLA-B7 ${ }^{+}$patients with MS and healthy subjects was also similar. With a $C D 8^{+} \mathrm{T}$ cell clone specific for the HLA-A11 restricted AVFDRKSDAK peptide of EBNA3B ${ }^{23}$ the killing of LCL from HLA-A11 ${ }^{+}$patients with MS and healthy subjects was also similar. These results indicate that EBV infected B cells from patients with MS can be killed by EBV specific $\mathrm{CD}^{+} \mathrm{T}$ cells just as readily as those from healthy subjects. The results are also consistent with our finding of normal HLA class I expression by LCL in patients with MS and provide further evidence that the decreased $T$ cell reactivity to LCL is not due to an LCL abnormality.

\section{Patients with MS can generate normal EBV specific cytotoxic $\mathbf{C D 8}^{+} \mathbf{T}$ cell lines in vitro}

One possible explanation for the decreased frequency of LCL specific $\mathrm{T}$ cells in patients with MS is a primary $\mathrm{T}$ cell defect. To investigate this, we generated $\mathrm{T}$ cell lines from 10 healthy subjects and 11 patients with MS by stimulating PBMC with irradiated autologous LCL. The T cell lines from six healthy subjects and six patients with MS specifically killed autologous LCL but not HLA mismatched LCL (table 4). The EBV specific T cell lines were composed predominantly of $\mathrm{CD}^{+} \mathrm{T}$ cells in most subjects. When tested against autologous LCL, the cytotoxic capacity of the $\mathrm{T}$ cell lines was similar in healthy subjects and patients with MS. These results indicate that, despite a lower frequency of EBV specific $T$ cells in patients with MS, EBV specific cytotoxic $\mathrm{CD}^{+} \mathrm{T}$ cell lines can be generated normally in vitro from these patients. Thus the decreased frequency of circulating LCL specific T cells cannot be explained by a primary $\mathrm{T}$ cell defect.

\section{Correlation between $\mathrm{T}$ cell and antibody immunity to EBV}

Levels of anti-EBNA1 IgG and anti-VCA IgG were quantified by titration of serum samples using ELISA (table 5). The geometric mean titre of anti-EBNA1 IgG was higher in patients with MS (1155) than in healthy subjects (720). The proportion of individuals with a high titre $(\geqslant 1600)$ of anti-EBNA1 IgG was also higher in the MS group than in the healthy control group although the difference was not significant. The median absorbance index for anti-EBNA1 IgG at a dilution of 1:200 was significantly higher in patients with MS (2.33) than in healthy subjects (2.13; $p=0.025)$. There was an inverse correlation between the anti-EBNA1 IgG titre and the LCL specific $T$ cell frequency $\left(r_{s}=-0.22, p=0.069\right)$ when the results from healthy subjects and patients with MS were combined. The geometric mean titre of anti-VCA IgG was similar in patients with MS and healthy subjects, as was the proportion of individuals with a titre $\geqslant 1600$. There was no correlation between the anti-VCA IgG titre and the LCL specific T cell frequency.

\section{DISCUSSION}

In this study, we have shown that patients with MS have decreased $\mathrm{T}$ cell immunity to EBV, as assessed by the frequency of PBMC producing IFN $\gamma$ in response to autologous LCL. In contrast to the use of synthetic EBV peptides as target antigens, this approach provides a direct measure of the aggregate $T$ cell response to EBV infected $B$ cells in each subject because it uses each person's natural antigen processing mechanisms to present viral antigens at normal physiological concentrations on the surface of their own EBV infected B cells and it represents the total $\mathrm{T}$ cell response to all EBV antigens presented by all HLA molecules on LCL in each subject. Furthermore, LCL stimulation 
Table 5 Titres of anti-EBNA1 $\lg G$ and anti-VCA $\lg G$ in serum

\begin{tabular}{lccccc}
\hline & \multicolumn{2}{l}{ Anti-EBNA1 IgG } & & \multicolumn{1}{c}{ Anti-VCA IgG } & \\
\cline { 2 - 3 } \cline { 5 - 6 } Titre & HC (n (\%)) & MS (n (\%)) & & HC (n (\%)) & MS (n (\%)) \\
\hline 50 & $2(6.1)$ & $0(0.0)$ & & $1(3.0)$ & $0(0.0)$ \\
100 & $1(3.0)$ & $0(0.0)$ & & $2(6.1)$ & $0(0.0)$ \\
200 & $5(15.2)$ & $3(8.8)$ & & $1(3.0)$ & $1(2.9)$ \\
400 & $6(18.2)$ & $6(17.6)$ & & $0(0.0)$ & $4(11.8)$ \\
800 & $7(21.2)$ & $7(20.6)$ & & $5(15.2)$ & $4(11.8)$ \\
1600 & $6(18.2)$ & $10(29.4)$ & & $9(27.3)$ & $15(44.1)$ \\
3200 & $2(6.1)$ & $4(11.8)$ & & $14(42.4)$ & $8(23.5)$ \\
6400 & $4(12.1)$ & $4(11.8)$ & & $1(3.0)$ & $1(2.9)$ \\
12800 & $0(0.0)$ & $0(0.0)$ & & $0(0.0)$ & $1(2.9)$ \\
GMT & 720 & 1155 & & 1440 & 1536 \\
$n(\%)$ titre $\geqslant 1600$ & $12(36.4)$ & $18(52.9)$ & & $24(72.7)$ & $25(73.5)$ \\
p Value* & & 0.17 & & 0.94 \\
\hline
\end{tabular}

${ }^{*} \chi^{2}$ test comparing proportions of $\mathrm{HC}$ and MS subjects with titre $\geqslant 1600$. EBNA1, Epstein-Barr virus nuclear antigen 1; GMT, geometric mean titre; HC, 33 healthy control subjects; MS, 34 patients with multiple sclerosis; VCA, viral capsid antigen.

detects responses not only to the latent proteins of EBV but also to the lytic proteins. ${ }^{13} 14$ Our finding of decreased $\mathrm{T}$ cell immunity to EBV in MS is not a reflection of a generalised depression in $\mathrm{T}$ cell immunity because patients with MS have normal $T$ cell responses to tetanus toxoid and concanavalin $A$ and increased responses to myelin antigens. ${ }^{24}$

By studying the $\mathrm{T}$ cell response to LCL in purified populations of $\mathrm{CD}^{+} \mathrm{T}$ cells, $\mathrm{CD}^{+} \mathrm{T}$ cells and $\mathrm{NK}$ cells, we have demonstrated that $\mathrm{CD}^{+} \mathrm{T}$ cells are the predominant population responding to EBV infected $B$ cells, with the frequency of EBV specific CD8+ $\mathrm{T}$ cells being 5-7-fold higher than the frequency of EBV specific $\mathrm{CD}^{+} \mathrm{T}$ cells, as previously reported. ${ }^{20}$

Our finding of decreased $\mathrm{T}$ cell immunity to LCL in MS differs from a previous small study on 11 patients which reported a non-significant increase in the frequency of LCL specific $\mathrm{CD}^{+} \mathrm{T}$ cells, as determined by intracellular cytokine flow cytometry. ${ }^{25}$ The most likely explanation for this discrepancy is the small sample size of that study. Our results are consistent with an early study reporting that patients with MS have decreased $T$ cell control of the number of Ig secreting $B$ cells after in vitro infection with EBV. ${ }^{8}$ A recent study using a pool of 18 HLA class I restricted EBV peptides in ELISPOT assays found an increased EBV specific $\mathrm{CD}^{+} \mathrm{T}$ cell response in patients with clinically isolated syndromes but a normal response in established MS. ${ }^{11}$ The results of that study are difficult to interpret because it is likely that in any given subject only a minority of the peptides in the peptide pool were restricted by HLA class I alleles carried by the subject. Thus the $\mathrm{T}$ cell response to the pool of peptides might have been composed largely of responses that have no in vivo relevance. It is noteworthy that the mean frequency of $\mathrm{T}$ cells responding to the pool of peptides in healthy subjects in that study was only $5 \%$ of the mean frequency of LCL specific T cells in healthy subjects in our study.

We have shown that the decreased $\mathrm{CD}^{+} \mathrm{T}$ cell response to LCL in MS is not due to decreased HLA class I expression on the LCL and that LCL from patients with MS can be killed normally by HLA matched EBV specific cytotoxic $\mathrm{CD}^{+} \mathrm{T}$ cell clones from healthy subjects. We have also shown that differences in HLA genes carried by patients with MS and healthy subjects do not account for the decreased $T$ cell response to LCL in MS. In addition, we have demonstrated that the decreased $\mathrm{CD}^{+} \mathrm{T}$ cell response to EBV infected $\mathrm{B}$ cells is not caused by a primary defect in the function of $\mathrm{CD}^{+} \mathrm{T}$ cells because EBV specific cytotoxic $\mathrm{CD}^{+} \mathrm{T}$ cell lines could be generated normally in vitro from PBMC of patients with MS. One possible explanation for the decreased $\mathrm{CD}^{+} \mathrm{T}$ cell immunity to EBV in $M S$ is impaired priming of EBV specific $\mathrm{CD}^{+} \mathrm{T}$ cells by dendritic cells. A limitation of our study is that we have not determined whether the decrease in $\mathrm{CD} 8^{+} \mathrm{T}$ cell immunity to EBV is accompanied by a decrease in $C D 8^{+} \mathrm{T}$ cell immunity to other infectious agents. Further studies will be required to investigate this.

Our finding of an elevated anti-EBNA1 IgG titre in patients with MS is consistent with previous reports. ${ }^{25-27}$ We also observed an inverse correlation between the anti-EBNA1 IgG titre and the anti-LCL T cell frequency, suggesting that the elevated anti-EBNA1 IgG titre might be a consequence of decreased $\mathrm{CD}^{+} \mathrm{T}$ cell immunity to EBV. Prospective studies of blood samples collected before the onset of MS have shown that elevated IgG reactivity to EBNA1 increases the risk of developing $\mathrm{MS}^{28-30}$

A fundamental question is whether the decreased frequency of EBV specific T cells in the blood is the cause or effect of the accumulation of EBV infected B cells in the CNS in $\mathrm{MS},{ }^{7}$ or a combination of both. Some of the decrease might be due to sequestration of EBV specific $\mathrm{CD}^{+} \mathrm{T}$ cells in the CNS. CD8 ${ }^{+} \mathrm{T}$ cells have been shown to be present in the CNS in proportion to the number of EBV infected $B$ cells ${ }^{7}$ but it is not known whether these $\mathrm{CD}^{+} \mathrm{T}$ cells are specific for EBV and whether they can recognise and kill EBV infected $\mathrm{B}$ cells in the CNS. If the decreased frequency of LCL specific $\mathrm{T}$ cells in the blood were to be attributed solely to sequestration within the CNS, it would beg the question why EBV infected B cells accumulate in the CNS in the first place and why are they not eliminated by EBV specific $\mathrm{CD}^{+} \mathrm{T}$ cells, given that we have shown that EBV infected $B$ cells of patients with MS can be killed by their own EBV specific $\mathrm{CD}^{+} \mathrm{T}$ cells. We suggest that the most likely scenario is that a genetically determined quantitative deficiency in the generation of EBV specific CD8 ${ }^{+} \mathrm{T}$ cells in vivo allows the accumulation of EBV infected B cells in the CNS in MS and that a vicious circle then ensues whereby the inherently deficient $\mathrm{CD}^{+} \mathrm{T}$ cell response is further compromised by $\mathrm{T}$ cell exhaustion $^{31}$ as a result of the persistent high EBV load in the CNS. It could be argued that the decrease in EBV specific CD8 ${ }^{+}$ $\mathrm{T}$ cell immunity in patients with MS reported here is of an insufficient degree to lead to the development of MS. However, in non-linear dynamic systems, such as those commonly occurring in biology and medicine, small changes in the initial condition of a system can produce dramatic changes in long term behaviour, sometimes referred to as the "butterfly effect". 32 33 Our finding that lower LCL specific T cell frequencies were associated with earlier age of onset of MS suggests that the more severe the defect in EBV specific $T$ cell immunity the sooner MS will develop after primary EBV infection. EBV specific CD8 ${ }^{+} \mathrm{T}$ cells can also be sequestered in the bone marrow ${ }^{34}$ but there is no reason to believe that this should occur to a greater extent in patients with MS than in healthy subjects.

In conclusion, the quantitative deficiency in $\mathrm{CD}^{+} \mathrm{T}$ cell immunity to EBV reported in the present study might predispose to the development of MS by allowing the accumulation of EBV infected autoreactive $\mathrm{B}$ cells in the CNS. ${ }^{6}$ Boosting $\mathrm{CD}^{+} \mathrm{T}$ cell immunity to EBV by vaccination or by transferring EBV specific cytotoxic $\mathrm{CD}^{+} \mathrm{T}$ cells may be beneficial in preventing and treating MS. 
Acknowledgements: We are grateful to Dr Kerryn Green, Tim O'Maley and Bernie Gazzard for assistance in clinically assessing patients and in the collection of blood samples.

Funding: This work was supported by project grants from Multiple Sclerosis Research Australia and by an unrestricted research grant from Biogen Idec Australia Pty Ltd.

Competing interests: None.

Ethics approval: This study was approved by the Royal Brisbane and Women's Hospital Human Research Ethics Committee and the University of Queensland Medical Research Ethics Committee.

\section{REFERENCES}

1. Sospedra M, Martin R. Immunology of multiple sclerosis. Annu Rev Immunol 2005;23:683-747.

2. Pender MP, Greer JM. Immunology of multiple sclerosis. Curr Allergy Asthma Rep 2007:7:285-92.

3. Ascherio A, Munger KL. Environmental risk factors for multiple sclerosis. Part I: The role of infection. Ann Neurol 2007;61:288-99.

4. Pohl D, Krone B, Rostasy K et al. High seroprevalence of Epstein-Barr virus in children with multiple sclerosis. Neurology 2006;67:2063-5.

5. Thorley-Lawson DA. Epstein-Barr virus: exploiting the immune system. Nat Rev Immunol 2001:1:75-82.

6. Pender MP. Infection of autoreactive B lymphocytes with EBV, causing chronic autoimmune diseases. Trends Immunol 2003;24:584-8.

7. Serafini B, Rosicarelli B, Franciotta D, et al. Dysregulated Epstein-Barr virus infection in the multiple sclerosis brain. J Exp Med 2007;204:2899-912.

8. Craig JC, Haire M, Merrett JD. T-cell-mediated suppression of Epstein-Barr virus induced B lymphocyte activation in multiple sclerosis. Clin Immunol Immunopathol 1988;48:253-60.

9. Höllsberg $\mathbf{P}$, Hansen HJ, Haahr S. Altered $\mathrm{CD}^{+} \mathrm{T}$ cell responses to selected Epstein-Barr virus immunodominant epitopes in patients with multiple sclerosis. Clin Exp Immunol 2003;132:137-43.

10. Gronen F, Ruprecht K, Weissbrich B, et al. Frequency analysis of HLA-B7-restricted Epstein-Barr virus-specific cytotoxic T lymphocytes in patients with multiple sclerosis and healthy controls. J Neuroimmunol 2006;180:185-92.

11. Jilek S, Schluep M, Meylan P, et al. Strong EBV-specific CD8+ T-cell response in patients with early multiple sclerosis. Brain 2008;131:1712-21.

12. Lünemann JD, Edwards N, Muraro PA, et al. Increased frequency and broadened specificity of latent EBV nuclear antigen-1-specific T cells in multiple sclerosis. Brain 2006;129:1493-506.

13. Pudney VA, Leese AM, Rickinson $A B$, et al. CD8+ immunodominance among Epstein-Barr virus lytic cycle antigens directly reflects the efficiency of antigen presentation in lytically infected cells. J Exp Med 2005;201:349-60.

14. Tynan FE, Elhassen D, Purcell AW, et al. The immunogenicity of a viral cytotoxic T cell epitope is controlled by its MHC-bound conformation. J Exp Med 2005;202:1249-60.

15. Polman CH, Reingold SC, Edan G, et al. Diagnostic criteria for multiple sclerosis: 2005 Revisions to the "McDonald Criteria". Ann Neurol 2005;58:840-6.

16. Kurtzke JF. Rating neurologic impairment in multiple sclerosis: an expanded disability status scale (EDSS). Neurology 1983:33:1444-52.
17. Roxburgh RHSR, Seaman SR, Masterman T, et al. Multiple Sclerosis Severity Score: using disability and disease duration to rate disease severity. Neurology 2005;64:1144-51.

18. Burrows SR, Silins SL, Moss DJ, et al. T cell receptor repertoire for a viral epitope in humans is diversified by tolerance to a background major histocompatibility complex antigen. J Exp Med 1995;182:1703-15.

19. Shi Y, Smith KD, Kurilla MG, et al. Cytotoxic CD8 ${ }^{+}$T cells recognize EBV antigen but poorly kill autologous EBV-infected B lymphoblasts. Immunodominance is elicited by a peptide epitope that is presented at low levels in vitro. J Immunol 1997;159:184452.

20. Yang J, Lemas VM, Flinn IW, et al. Application of the ELISPOT assay to the characterization of $\mathrm{CD}^{+}$responses to Epstein-Barr virus antigens. Blood 2000;95:241-8

21. Harbo HF, Lie BA, Sawcer S, et al. Genes in the HLA class I region may contribute to the HLA class II-associated genetic susceptibility to multiple sclerosis. Tissue Antigens 2004;63:237-47

22. Hill AB, Lee SP, Haurum JS, et al. Class I major histocompatibility complex-restricted cytotoxic T lymphocytes specific for Epstein-Barr virus (EBV)-transformed B lymphoblastoid cell lines against which they were raised. $J$ Exp Med 1995; 181:2221-8.

23. Steven NM, Leese AM, Annels NE, et al. Epitope focusing in the primary cytotoxic $T$ cell response to Epstein-Barr virus and its relationship to T cell memory. J Exp Med 1996;184:1801-13.

24. Greer JM, Csurhes PA, Muller DM, et al. Correlation of blood T cell and antibody reactivity to myelin proteins with HLA type and lesion localization in multiple sclerosis. $\mathrm{J}$ Immunol 2008;180:6402-10.

25. Cepok S, Zhou D, Srivastava R, et al. Identification of Epstein-Barr virus proteins as putative targets of the immune response in multiple sclerosis. J Clin Invest 2005; 115:1352-60

26. Larsen PD, Bloomer LC, Bray PF. Epstein-Barr nuclear antigen and viral capsid antigen antibody titers in multiple sclerosis. Neurology 1985;35:435-8.

27. Sumaya CV, Myers LW, Ellison GW, et al. Increased prevalence and titer of Epstein-Barr virus antibodies in patients with multiple sclerosis. Ann Neurol 1985;17:371-7.

28. Ascherio A, Munger KL, Lennette ET, et al. Epstein-Barr virus antibodies and risk of multiple sclerosis: a prospective study. JAMA 2001;286:3083-8.

29. Sundström $\mathbf{P}$, Juto $P$, Wadell $G$, et al. An altered immune response to Epstein-Barr virus in multiple sclerosis: a prospective study. Neurology 2004:62:2277-82.

30. Levin LI, Munger KL, Rubertone MV, et al. Temporal relationship between elevation of Epstein-Barr virus antibody titers and initial onset of neurological symptoms in multiple sclerosis. JAMA 2005;293:2496-500.

31. Klenerman $\mathbf{P}$, Hill A. T cells and viral persistence: lessons from diverse infections Nat Immunol 2005:6:873-9.

32. Goldberger AL. Non-linear dynamics for clinicians: chaos theory, fractals, and complexity at the bedside. Lancet 1996:347:1312-14.

33. Goldberger AL, Giles F. Filley Lecture. Complex systems. Proc Am Thorac Soc 2006;3:467-72.

34. Palendira U, Chinn R, Raza W, et al. Selective accumulation of virus-specific CD8 ${ }^{+}$ cells with unique homing phenotype within the human bone marrow. Blood 2008:112:3293-302. 